\title{
STUDI PERANCANGAN JARINGAN WORLDWIDE INTEROPERABILITY FOR MICROWAVE ACCESS (WiMAX) DI AREA BANYUMAS
}

\author{
Alfin Hikmaturokhman ${ }^{1} \sim$ Anggun Fitrian Isnawati ${ }^{2} \sim$ Ike Lestari $^{3}$ \\ Program Studi D-III Teknik Telekomunikasi \\ Akademi Teknik Telekomunikasi Sandhy Putra Purwokerto \\ Alfin_h21@yahoo.com, anggun_fitrian@yahoo.com, iles_cb@yahoo.com
}

\begin{abstract}
ABSTRAK
Saat ini kebutuhan akan internet semakin tinggi seiring dengan perkembangan jaman yang semakin maju. Maka ada terobosan terbaru dalam bidang telekomunikasi yaitu WiMAX yang merupakan teknologi broadband wireless dengan standar IEEE 802.16. Teknologi jaringan WiMAX hadir dengan keunggulan di aspek kecepatan akses data, luas daerah jangkauan dan hadirnya QoS yang dapat mengalokasikan frekuensi sesuai dengan kebutuhan user menggunakan teknologi OFDM. Teknologi WiMAX dapat menjangkau area sejauh 50 kilometer, juga memungkinkan peralatan pengguna (customer premise equipment atau CPE) untuk mendapatkan hubungan broadband tanpa harus ada lintasan langsung (non line of sight, NLOS) ke base station (BS) dan menyediakan total data rate hingga 75 Mbps. Hasil Penelitian ini diasumsikan daerah yang akan jadi tempat perancangan adalah Kabupaten Banyumas. Maka dapat diperoleh nilai $\mathrm{P}_{\mathrm{Rx}}$ sebesar $-100,31 \mathrm{~dB}$; nilai Total Margin sebesar 23,56 dB; Path loss sebesar 134,5 dB; gamma $(\gamma)$ sebesar 4,375; Faktor koreksi frekuensi $(\Delta \mathrm{PLf})$ sebesar 0,36; Faktor koreksi antena ( $\Delta \mathrm{PLh})$ adalah -3,25; Radius Sel (d) adalah sebesar 1995 meter; Luas Sel adalah sebesar 10,34010495 $\mathrm{km}^{2}$ dan jumlah sel adalah 133 .
\end{abstract}

Kata kunci : WiMAX, Banyumas, Radius Sel, Jumlah Sel

\begin{abstract}
At present the need for higher internet connection along with the age which is growing so fast. Then there is the latest breakthrough in telecomunications that is WiMAX technology is a wireless broadband technology reffered the IEEE 802.16 standard. WiMAX technology comes with a network of excellence in aspects of data access speed, wide area coverage and the presence of QoS is can allocate frequencies in accordance with user needs using OFDM technology. WiMAX technology can reach area far as 50 kilometers, also allows user equipment (customer premise equipment or CPE) to get a broadband connection without having a direct path (non line of sight, NLOS) to the base station (BS) and provides a total data rate of up to 75 Mbps. Results of this Final project assumed that the area where will be design is Banyumas district. Then final project results of the $P_{R X}-100.31 \mathrm{~dB}$; the Total Margin of 23.56 dB; Path los of 134.5 dB; gamma ( $\left.\gamma\right)$ of 4.375; Frequency correction

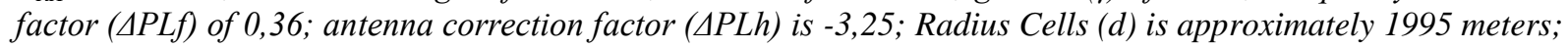
area of cell is at 10,34010495 km2 and the number of cells 133 .
\end{abstract}

Keywords: WiMAX, Banyumas, Radius Cells, The Number of Cell

\section{PENDAHULUAN}

\section{1. Latar Belakang}

Teknologi telekomunikasi menentukan kemajuan suatu bangsa. Ketersedian sarana telekomunikasi menjadi faktor penting bagi katalisator pembangunan suatu wilayah. Suatu daerah membutuhkan sarana telekomunikasi dan informasi untuk mempromosikan produk unggulan daerahnya atau daerah pariwisatanya.
Indonesia sebagai negara kepulauan terbesar di dunia. Adanya hambatan geografis yang lebih tinggi daripada negara-negara lain membuktikan bahwa diperlukan ketersediaaan sarana telekomunikasi yang jauh lebih advance, yaitu sarana telekomunikasi yang mampu mengintegrasikan satu daerah dengan daerah lain, satu pulau dengan pulau lain. Perkembangan telekomunikasi di dunia pun 
berkembang begitu pesat. Standar telekomunikasi seluler seperti AMPS, GSM, CDMA telah berevolusi sedemikian cepat. Kini hadir terobosan terbaru dalam dunia telekomunikasi yaitu Worldwide Interoperability for Microwave Access (WiMAX) merupakan teknologi broadband yang memiliki kecepatan akses yang tinggi dan jangkauan yang luas dan juga merupakan evolusi dari Broadband Wireless Access (BWA) sebelumnya dengan fitur-fitur yang lebih menarik. WiMAX diciptakan untuk menyongsong era baru teknologi masa depan atau biasa disebut Next Generatin Network (NGN). Berbagai keunggulan bisa didapatkan dari teknologi WiMAX ini. Secara teknis, teknologi WiMAX memiliki banyak fitur yang selama ini belum terdapat pada teknologi WiFi dengan standarnya IEEE 802.11 sehingga dapat melayani area yang lebih luas. Dari segi cakupannya yang sejauh $50 \mathrm{~km}$ maksimal, WiMAX dapat menghantarkan data dengan transfer rate jarak jauh tersebut tentu akan menutup semua celah broadband yang ada saat ini. Dari segi kondisi saat proses komunikasinya, teknologi WiMAX dapat melayani para subscriber, baik yang berada dalam posisi Line Of Sight (LOS) yaitu posisi perangkat-perangkat yang ingin berkomunikasi masih berada dalam jarak pandang yang lurus dan bebas dari penghalang apapun dengan BTS maupun yang tidak memungkinkan untuk itu atau pada kondisi Non Line Of Sight (Non LOS).

Teknologi WiMAX ini sangat
dibutuhkan untuk daerah-daerah dengan
pengguna internet yang cukup banyak agar memudahkan pengguna untuk dapat berkomunikasi tanpa ada suatu hambatan. Tentunya harus disesuaikan dengan area dan kebutuhan bit rate dari daerah tersebut. dengan kondisi tersebut maka penulis akan melakukan perancangan WiMAX dilihat dari parameterparameter yang ada seperti Laju Bit Sistem, Path Loss, Receive Signal Level, Free Space Loss (FSL), dan jumlah sel agar memungkinkan penduduk area Banyumas bisa melakukan aktifitas dengan internet secara efektif dan efisien.

Dari penjelasan tersebut, maka dapat diketahui masalah yaitu bagaimana proses perancangan jaringan Worldwide Interoperability For Microwave Access (WiMAX), khususnya di daerah Banyumas.

\subsection{Tujuan Penulisan}

Dari penjelasan diatas, tujuan yang ingin dicapai dari penulisan ini adalah :

1. Merancang jaringan Worldwide
Interoperability For Microwave Access (WiMAX), khususnya di daerah Banyumas.

2. Mengkaji dan memahami tentang cara kerja WiMAX serta perangkat-perangkat yang ada di dalamnya.

\subsection{Batasan Masalah}

Adapun batasan masalah yang akan dibahas pada penelitian ini adalah sebagai berikut:

1. Perancangan disesuaikan dengan keadaan daerah Banyumas.

2. Menggunakan frekuensi $2,3 \mathrm{GHz}$ atau antara 2300-2390 MHz. 
3. Perhitungan parameter WiMAX seperti Path Loss, Radius sel, luas sel dan jumlah sel.

4. Menggunakan WiMAX dengan tipe mobile WiMAX

5. Perancangan menggunakan pendekatan luas wilayah.

6. Menggunakan product vendor WiMAX yaitu TRG (Teknologi Riset Global ).

7. Menggunakan Software Visual Basic 6.0 dalam proses perhitungan parameter WiMAX

\section{KAJIAN PUSTAKA}

\subsection{Teknologi Worldwide Interoperability} For Microwave Access (WiMAX)

WiMAX forum telah menetapkan standar IEEE (Institute of Electrical and Electronics Engineering) 802.16 sebagai IEEE 802.162004 yang digunakan peralatan wireless broadband pada frekuensi industry, scientific, and medical (ISM) maupun pita frekuensi lainnya. Sebagai standar hubungan radio fixed point-to-point $(\mathrm{P} 2 \mathrm{P})$ maupun untuk point-tomultipoint (PMP). WiMAX adalah teknologi jaringan wireless metropolitan area yang saling mendukung (interoperable) pada broadband wireless untuk penggunaan fixed, portable dan nomadic. Teknologi ini dapat menjangkau area sejauh 50 kilometer, juga memungkinkan peralatan pengguna (customer premise equipment atau CPE) untuk mendapatkan hubungan broadband tanpa harus ada lintasan langsung (non line of sight, Non LOS) ke Base Station (BS) dan menyediakan total data rate hingga 75 Mbps, suatu bandwidth yang cukup untuk melayani ratusan pelanggan dalam satu $\mathrm{BS}^{[5]}$.

Akses untuk komunikasi data pada WLAN menggunakan standar IEEE 802.11, dan biasa disebut wireless fidelity (Wi-Fi). Saat ini Wi-Fi telah banyak diimplementasikan untuk komunikasi data dengan menggunakan PC atau Laptop. Wi-Fi sangat membantu dalam implementasi infrastruktur jaringan komunikasi data. Wi-Fi memiliki daerah jangkauan yang terbatas, kualitas layanan (Quality of Services atau QoS) yang masih sederhana, spektrum frekuensi yang digunakan bisa pada spektrum frekuensi lisensi dan tidak lisensi dan kapasitasnya terbatas. Karena keterbatasan jangkauan Wi-Fi serta tuntutan mobilitas pengguna, maka dikembangkan teknologi WiMAX dengan menggunakan standar IEEE 802.16a. Bila dibandingkan dengan Wi-Fi, WiMAX memiliki keunggulan dalam kapasitas, kecepatan dan QoS yang lebih baik.

\subsection{Sistem Orthogonal Frequency Division Multiplexing (OFDM)}

WiMAX merupakan teknologi akses nirkabel pita lebar yang dibangun berdasarkan standar IEEE (Institute of Electrical and Electronics Engineering) 802.16 yang didesain untuk memenuhi kondisi non-LoS (Line of Sight) dan menggunakan teknik modulasi adaptif, seperti QPSK,QAM 16, dan QAM 64. WiMAX dapat digunakan sebagai alternatif kabel modem dan layanan DSL serta sebagai backhaul untuk beberapa hotspot Wi-Fi. WiMAX merupakan tekhnologi OFDM. OFDM merupakan sebuah teknik multiplexing 
sinyal, yang membagi sebuah sinyal menjadi beberapa kanal dengan pita frekuensi yang sempit dan saling berdekatan, dengan setiap kanal menggunakan frekuensi yang berbeda. Jangkauan operasi WiMAX cukup luas, sehingga WiMAX dapat menjadi infrastruktur yang tepat untuk meningkatkan kebutuhan internet.

Pada teknik transmisi OFDM setiap subcarrier tidak ditempatkan berdasarkan bandwidth yang ada, tetapi sub-carrier tersebut disusun untuk saling overlapping. Jarak atau space antara sub-carrier diatur sedemikian rupa, sehingga antara sub-carrier mempunyai sifat yang orthogonal. Keorthogonalitasan diantara sub-carrier inilah yang menyebabkan munculnya istilah Orthogonal Frequency Division Multiplexing. Dengan menggunakan teknik overlapping ini dapat menghemat bandwidth kanal sampai dengan $50 \%$. Untuk pembentukan dan penguraian symbol OFDM dapat digunakan Inverse Fast Fourier Transform (IFFT) dan Fast Fourier Transform $(\mathrm{FFT})^{[1]}$.

Symbol OFDM ditambahkan cyclic prefix kemudian simbol-simbol OFDM dikonversikan lagi kedalam bentuk serial, dan kemudian sinyal dikirim. Sinyal keluaran dari transmitter berupa sinyal yang saling overlapping, hal seperti ini dapat menghemat bandwidth kanal sampai $50 \%$. Kondisi overlapping ini tidak akan menimbulkan interferensi dikarenakan telah memenuhi kondisi orthogonal. Pada receiver, dilakukan operasi yang berkebalikan dengan apa yang dilakukan di stasiun pengirim. Mulai dari konversi dari serial ke paralel, pelepasan cyclic prefix kemudian konversi sinyal paralel dengan FFT setelah itu demodulasi, dan akhirnya konversi paralel ke serial dan akhirnya kembali menjadi bentuk data informasi ${ }^{[1]}$.

\subsection{Standarisasi WiMAX}

WiMAX memang dirancang untuk mampu melayani berbagai servis yang tersedia. Ini sangat diperlukan karena semua orang akan membutuhkan hubungan koneksi ke jaringan internet kapanpun dan di manapun pengguna berada. Beberapa perusahaan saat ini membutuhkan jaringan agar dapat berkomunikasi dengan para kliennya dan itu membutuhkan waktu yang lama dan biaya yang cukup mahal jika dilakukan secara manual. Tetapi jika di setiap tempat telah terdapat jaringan wireless, dan setiap orang bisa terhubung ke jaringan, maka resiko dan biaya yang akan dihadapi jika dilakukan secara manual dapat dihindari dengan adanya jaringan wireless tersebut. Salah satu solusinya adalah dengan media wireless ini. Dengan adanya standarisasi Wireless MAN yang ditetapkan oleh IEEE ini, maka kebutuhan untuk dapat terkoneksi ke jaringan tersebut dapat terpenuhi.

Berikut ini adalah jenis standarisasi yang ditetapkan oleh WiMAX forum terhadap perkembangan teknologi WiMAX ${ }^{[13]}$.

1. WiMAX 802.16

Standar ini mengatur pemanfaatan di band frekuensi 10-66 GHz. Aplikasi yang mampu didukung baru sebatas dalam kondisi LOS.

2. WiMAX 802.16a 
Frekuensi 2-11 GHz dapat digunakan untuk lingkungan Non-Line of Sight. Standar ini difinalisasi pada januari 2003

3. WiMAX 802.16d

WiMAX tipe ini merupakan standar yang berbasis 802.16 dan 802.16a dengan berbagai perbaikan. WiMAX 802.16d diperuntukkan bagi layanan yang bersifat fixed maupun nomadic. Terdapat dua opsi dalam transmisi pada 802.16d, yaitu TDD (Time Division Duplex) maupun FDD (Full Division Duplex).

4. WiMAX 802.16e

Standar Wimax 802.16e mendukung untuk aplikasi portable dan mobile sehingga dikondisikan mampu hand-off dan roaming. Sistem ini menggunakan teknik Scalable Orthogonal Frequency Division Multiplexing Access (SOFDMA).

\subsection{Perangkat WiMAX}

Perangkat atau elemen WiMAX secara umum terdiri dari Base Station (BS) di sisi pusat dan CPE di sisi pelanggan. Namun demikian, masih ada perangkat tambahan seperti : antena, kabel dan aksesoris lainnya. Adapun penjelasan dari masing-masing perangkat WiMAX adalah sebagai berikut ${ }^{[13]}$ :

\section{Base station (BS)}

Merupakan perangkat transceiver (transmitter dan receiver) yang dipasang satu lokasi (collocated) dengan jaringan Internet Protocol (IP). Dari BS ini akan disambungkan ke beberapa CPE dengan media interface gelombang radio (RF) yang mengikuti standar WiMAX.
2. Customer Premisses Equipment (CPE) atau Subscriber Station (SS)

Secara umum, Customer Premisses Equipment (CPE) atau Subscriber Station (SS) terdiri dari Outdoor Unit (ODU) dan Indoor Unit (IDU), perangkat radionya ada yang terpisah dan ada yang terintegrasi. Perangkat SS ini bekerja pada range frekuensi 3300-3800Mhz..

3. Antena WiMAX

Antena WiMAX, seperti halnya antena yang digunakan pada radio mobil, telepon seluler, radio FM, atau TV, didesain untuk mengoptimalkan kinerja terhadap penerima sinyal. Ada tiga tipe utama antena yang biasa digunakan untuk pengembangan WiMAX

\section{PERANCANGAN PROGRAM}

\subsection{Tahap- tahap Pembuatan Program}

Rancangan program untuk menghitung perencanaan WiMAX di area Banyumas dengan alat bantu yaitu visual basic 6.0

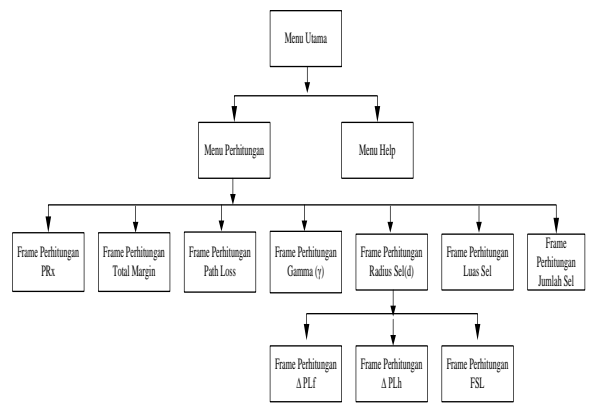

Gambar 1. Bagan Perencanaan Program dengan Visual Basic 6.0

Pada Gambar 2 merupakan tampilan form utama yang berisi beberapa dua label yaitu label perhitungan perancangan WiMAX, yang 
digunakan untuk menghitung tahapan perancangan jaringan dan 'Help'.

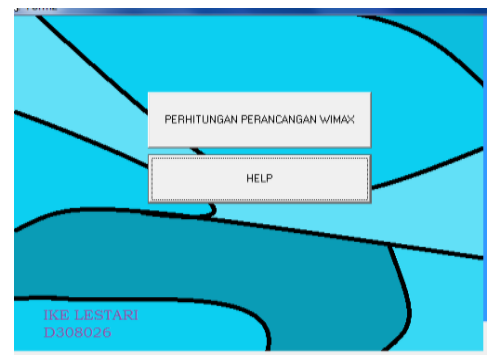

Gambar 2. Tampilan Form Utama Perancangan WiMAX

\section{Analisa dan Pembahasan}

\subsection{Perbandingan Perhitungan}

$$
\begin{aligned}
P_{\mathrm{RX}}= & \mathrm{SNR}+\mathrm{N} \\
= & \mathrm{SNR}+(\text { Thermal noise }+ \\
& \text { receiver noise figure }) \\
= & -3,31+(-104+7) \\
= & -100,31 \mathrm{dBm}
\end{aligned}
$$

Total Margin $=$ Log normal fade margin + Fast fading margint Interference margin +Building penetration loss

Total margin $=5,56+6+2+10$

$$
=23,56 \mathrm{~dB}
$$

$$
\begin{aligned}
& \text { Path loss }=\mathrm{P}_{\mathrm{TX}}+\mathrm{G}_{\mathrm{TX}}-\mathrm{L}_{\mathrm{TX}}-\mathrm{P}_{\mathrm{RX}}-\text { margin } \\
& =43+15-0,5-(-100,31)-23,56 \\
& =134,5 \mathrm{~dB} \\
& \gamma=\left(\mathrm{a}-\mathrm{b} \cdot \mathrm{hb}+\frac{c}{h b}\right) \\
& =\left(4-0,0065.30+\frac{17,1}{30}\right) \\
& =4,375
\end{aligned}
$$

\section{Perhitungan menggunakan frekuensi $1900 \mathrm{MHz}$}

Untuk menghitung nilai Radius Sel (d), perlu menghitung terlebih dahulu nilai $\Delta \mathrm{PLf}$ sesuai dengan persamaan 3.6:

$$
\begin{aligned}
\Delta \mathrm{PLf} & =\left(6 \log \frac{f}{2000}\right) \\
& =\left(6 \log \frac{1900}{2000}\right) \\
& =-0,133
\end{aligned}
$$

$$
\begin{aligned}
\Delta \mathrm{PLh} & =-10,8 \log _{10}\left(\frac{h m}{2}\right) \\
& =-10,8 \log _{10}\left(\frac{4}{2}\right) \\
& =-3,25
\end{aligned}
$$

$$
d=\left(10 \frac{P l-20 \log \left(\frac{4 \pi d 0 f}{c}\right)-\triangle P L f+\Delta P L h}{10 \gamma}\right) d_{0}
$$

$d=$

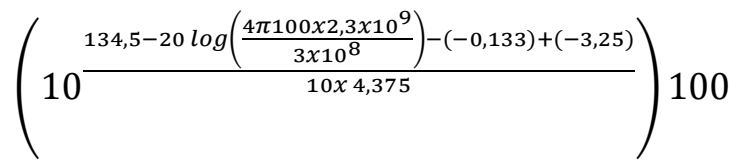

$\mathrm{d}=2238$ meter

Luas Sel $(L)=2,598(d)^{2}$

$$
\begin{aligned}
& =2,598(2238)^{2} \\
& =13,012457112 \mathrm{~km}^{2}
\end{aligned}
$$

$$
\begin{aligned}
& \sum \text { sel }=\frac{\text { Luas wilayah }}{\text { Luas sel }} \\
& \quad=\frac{1327,60}{13,012457112} \\
& =102,12 \\
& \pm 103 \text { sel atau base station }
\end{aligned}
$$




\section{Perhitungan menggunakan frekuensi}

\section{$2100 \mathrm{MHz}$}

$$
\begin{aligned}
\Delta \mathrm{PLf} & =\left(6 \log \frac{f}{2000}\right) \\
& =\left(6 \log \frac{2100}{2000}\right) \\
& =0,127
\end{aligned}
$$

$$
\Delta \mathrm{PLh}=-10,8 \log _{10}\left(\frac{h m}{2}\right)
$$$$
=-10,8 \log _{10}\left(\frac{4}{2}\right)
$$$$
=-3,25
$$

$$
d=\left(10^{\frac{P l-20 \log \left(\frac{4 \pi d 0 f}{c}\right)-\Delta P L f+\Delta P L h}{10 \gamma}}\right) d_{0}
$$

$$
d=
$$

$\left(10 \frac{134,5-20 \log \left(\frac{4 \pi 100 \times 2,3 \times 10^{9}}{3 \times 10^{8}}\right)-(0,127)+(-3,25)}{10 \times 4,375}\right) 100$

$\mathrm{d}=2113$ meter

Luas Sel $(\mathrm{L})=2,598(\mathrm{~d})$

$$
\begin{aligned}
& =2,598(2113) \\
& =11,599469862 \mathrm{~km}^{2}
\end{aligned}
$$

$$
\begin{aligned}
\sum \text { sel } & =\frac{\text { Luas wilayah }}{\text { Luas sel }} \\
& =\frac{1327,60}{11,599469862} \\
& =120,69 \\
& \pm 121 \text { sel atau base station }
\end{aligned}
$$

\section{Perhitungan menggunakan frekuensi $2300 \mathrm{MHz}$}

Untuk menghitung nilai Radius Sel (d), perlu menghitung terlebih dahulu nilai $\Delta \mathrm{PLf}$ sesuai dengan persamaan 3.6:

$$
\begin{aligned}
& \Delta \mathrm{PLf}=\left(6 \log \frac{f}{2000}\right) \\
& =\left(6 \log \frac{2300}{2000}\right) \\
& =0,36 \\
& \Delta \mathrm{PLh}=-10,8 \log _{10}\left(\frac{h m}{2}\right) \\
& =-10,8 \log _{10}\left(\frac{4}{2}\right) \\
& =-3,25 \\
& d=\left(10^{\frac{P l-20 \log \left(\frac{4 \pi d 0 f}{c}\right)-\Delta P L f+\Delta P L h}{10 \gamma}}\right) \\
& d= \\
& \left(10 \frac{134,5-20 \log \left(\frac{4 \pi 100 \times 2,3 \times 10^{9}}{3 \times 10^{8}}\right)-(0,36)+(-3,25)}{10 \times 4,375}\right) 100 \\
& \text { d= } 1995 \text { meter }
\end{aligned}
$$

Luas Sel $(\mathrm{L})=2,598(\mathrm{~d})^{2}$

$$
\begin{aligned}
& =2,598(1995) \\
& =10,34010495 \mathrm{~km}^{2}
\end{aligned}
$$

$$
\begin{aligned}
\sum \text { sel } & =\frac{\text { Luas wilayah }}{\text { Luas sel }} \\
& =\frac{1327,60}{10,34010495} \\
& =132,76 \\
& \pm 133 \text { sel atau base station }
\end{aligned}
$$


4. Perhitungan menggunakan frekuensi 2500 $\mathrm{MHz}$

$$
\begin{aligned}
\Delta \mathrm{PLf} & =\left(6 \log \frac{f}{2000}\right) \\
& =\left(6 \log \frac{2500}{2000}\right) \\
& =0,58 \\
\Delta \mathrm{PLh} & =-10,8 \log _{10}\left(\frac{h m}{2}\right) \\
& =-10,8 \log _{10}\left(\frac{4}{2}\right) \\
& =-3,25
\end{aligned}
$$

$$
d=\left(10^{P l-20 \log \left(\frac{4 \pi d 0 f}{c}\right)-\Delta P L f+\Delta P L h} \frac{10 \gamma}{10 \gamma}\right) d_{0}
$$$$
\begin{gathered}
d= \\
\left(10 \frac{134,5-20 \log \left(\frac{4 \pi 100 \times 2,3 \times 10^{9}}{3 \times 0^{8}}\right)-(0,58)+(-3,25)}{10 \times 4,375}\right) 100
\end{gathered}
$$

$\mathrm{d}=1883$ meter

$$
\begin{aligned}
\operatorname{Luas} \operatorname{Sel}(\mathrm{L}) & =2,598(\mathrm{~d})^{2} \\
& =2,598(1883)^{2} \\
& =9,21170002
\end{aligned}
$$

$$
\begin{aligned}
\sum \mathrm{sel} & =\frac{\text { Luas wilayah }}{\text { Luas sel }} \\
& =\frac{1327,60}{9,211700022} \\
& =147,51 \\
& \pm 148 \text { sel atau base station }
\end{aligned}
$$

Jika hasil perhitungan perancangan WiMAX dengan menggunakan frekuensi $1900 \mathrm{MHz}, 2100 \mathrm{MHz}, 2300 \mathrm{MHz}$, dan 2500
MHz tersebut di plot, maka akan didapatkan grafik seperti pada Gambar 4.34.

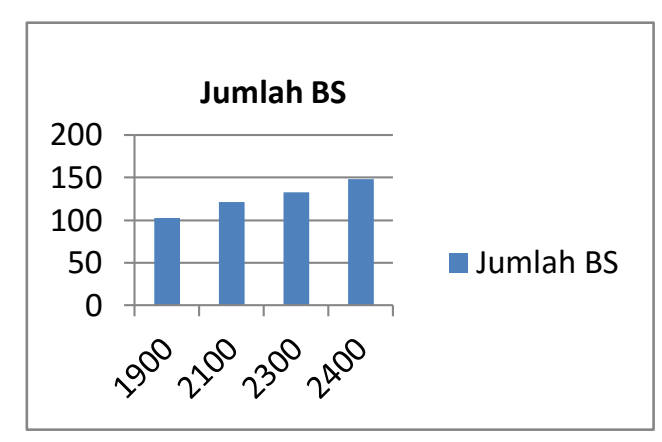

Gambar 3. Grafik Perbandingan

Frekuensi (MHz) dengan Jumlah Sel

(Base Station)

Dari grafik pada Gambar 3 terlihat bahwa frekuensi dan jumlah sel (BS) berbanding lurus. Hal ini dapat diartikan bahwa semakin besar frekuensi yang digunakan, maka semakin banyak juga jumlah sel atau base station (BS). Hal ini mengakibatkan sinyal yang dipancarkan untuk suatu wilayah seharusnya semakin bagus.

Sehingga dari hasil perbandingan sample Frekuensi (MHz) dengan Jumlah Sel (BS) untuk frekuensi $1900 \mathrm{MHz}, 2100 \mathrm{MHz}$, $2300 \mathrm{MHz}$, dan $2500 \mathrm{MHz}$, maka dapat disimpulkan bahwa jumlah sel untuk frekuensi $2100 \mathrm{MHz}$ lebih besar dari frekuensi 1900 $\mathrm{MHz}$, kemudian jumlah sel atau base station untuk frekuensi $2300 \mathrm{MHz}$ lebih besar daripada frekuensi $2100 \mathrm{MHz}$ serta jumlah sel atau BS untuk frekuensi $2500 \mathrm{MHz}$ lebih besar daripada frekuensi $2300 \mathrm{MHz}$. Penempatan frekuensi tentunya disesuaikan dengan kondisi wilayah yang akan di rancang WiMAX. 


\section{KESIMPULAN}

Berdasarkan hasil analisis dan pembahasan dapat diambil kesimpulan sebagai berikut:

1. Perancangan WiMAX untuk area

Banyumas dilakukan dengan beberapa proses yaitu:

a. Menghitung nilai Daya Output Receiver $\left(\mathrm{P}_{\mathrm{RX}}\right)$ yang didapat dari parameter Signal Noise to Ratio (SNR), Thermal Noise dan Noise Figure.

b. Menghitung nilai Total Margin yang di dapat dari hasil penjumlahan parameter $\log$ Normal Fade Margin, Fast Fading Margin, Interference Margin dan Building Penetration Loss.

c. Menghitung nilai Path Loss di dapat dari nilai Daya Output Transmitter $\left(\mathrm{P}_{\mathrm{TX}}\right)$, Gain Antenna $\left(\mathrm{G}_{\mathrm{TX}}\right)$, Loss Transmitter $\left(\mathrm{L}_{\mathrm{TX}}\right)$, Daya Output Receiver $\left(\mathrm{P}_{\mathrm{RX}}\right)$ serta Total Margin.

d. Menghitung radius sel (d) yang di dapat dari perhitungan nilai Path Loss, Faktor Koreksi Frekuensi ( $\triangle \mathrm{PLf}$ ), Faktor Koreksi Antenna $(\Delta \mathrm{PLh})$ serta nilai Gamma $(\gamma)$.

e. Menghitung nilai luas sel yang di dapat dari konstanta $\left(2,598\right.$ atau $\left.\frac{3 \sqrt{3}}{2}\right)$ dikalikan dengan radius sel (d).

f. Menghitung jumlah Base Station yang di dapat merupakan hasil pembagian dari luas wilayah dengan jumlah sel.

2. Hasil dari perancangan WiMAX area Banyumas yang telah dilakukan yaitu :

a. $\mathrm{P}_{\mathrm{Rx}}$ sebesar $-100,31 \mathrm{~dB}$.

b. Total Margin sebesar 23,56 dB.

c. Path loss sebesar 134,5 dB. d. Gamma $(\gamma)$ sebesar 4,375.

e. Faktor koreksi frekuensi ( $\triangle \mathrm{PLf}$ ) sebesar 0,36 sedangkan untuk nilai Faktor koreksi antena $(\triangle \mathrm{PLh})$ adalah $-3,25$.

f. Nilai radius sel (d) adalah sebesar 1995 meter.

g. Nilai luas sel adalah sebesar 10,34010495 $\mathrm{km}^{2}$ dan jumlah sel adalah 133 .

\section{DAFTAR PUSTAKA}

[1] Abdillah, Kusuma, dan Moegiharto, Yoedy. Analisa Kinerja Orthogonal Frequency Division Multiplexing (OFDM) Berbasis Perangkat Lunak. Jurnal. Poliktenik Elektro Negeri Surabaya - Institut Teknologi Sepuluh November (PENS-ITS).

[2] Ahmadi, Sassan. 2006. Introduction to mobile WiMAX Radio Access Technology : PHY and MAC Architecture.Wireless Standards and Technologhy Intel Corporotion. pdf.

[3] Deny Satria, Denden Kristianto, Syaiful Ahdan. 2009. Upgrading Teknologi Wifi ke Teknologi Wimax BWA Sebagai Media Komunikasi Data Pada PT. Aplikanusa Lintasarta Bandar Lampung. Seminar Nasional Aplikasi Teknologi Informasi 2009 (SNATI 2009), ISSN : 1907-5022.

[4] Faturohman,Taufik. 2011. Analisis Tekno-Ekonomi Perencanaan Teknologi Long Term Evolution (LTE) di kota Tasikmalaya. Jurnal. Universitas Jenderal Soedirman. 
[5] Helfin. 2007. Mengenal Lebih Jauh Tentang Wimax.

http://ilmukomputer.com/wpcontent/uploads/2007/06/helfinwimax.pdf. diakses tanggal 30 Agustus 2011 pukul 20.15 WIB.

[6] Hermawan, C Widyo. 2009. Kupas Tuntas Teknologi WiMAX. Yogyakarta: ANDI dan Wahana Komputer.

[7] Mardhiko, Dimass Nolly. Perencanaan Jaringan Akses Mobile WiMAX (WORLDWIDE INTEROPERABILITY FOR MICROWAVE ACCESS) 2,5 GHz untuk Wilayah DKI Jakarta. Jurnal. Universitas Jenderal Soedirman.

[8] Maylitha, Shufi. 2009. Analisis Large Scale Fading dengan Model LEE Menggunakan Visual Basic sebagai Alat Bantu. Tugas Akhir. Akatel Sandhy Putra Purwokerto.

[9] Pramono, Catur. Pemodelan Kanal SUI pada Sistem Komunikasi WiMAX. Makalah Seminar Tugas Akhir. Universitas Diponogoro.

[10] Prasetio, Muhammad Bayu.2009. Studi Perancangan Jaringan WIMAX di Daerah Urban (Studi Kasus:Kota Medan). Tugas Akhir. Universitas Sumatera Utara.

http://repository.usu.ac.id/bitstream/123 456789/11844/1/10E00463.pdf. diakses tanggal 15 Agustus 2011 Pukul 15.25 WIB.

[11] Siahaan, SM Bobby. 2008. Analisis Perbandingan Perfomansi Worldwide
Interoperability for Microwave Access (WiMAX) dan Asymetric Digital Subscriber Line (ADSL) untuk Efektifitas Layanan Multimedia. Tugas Akhir. Akatel Sandhy Putra Purwokerto.

[12] Simorangkir, Chandra. 2009. Perhitungan Pembiasan DC pada Transistor Dwi Kutub NPN dengan Visual Basic 6.0. Tugas Akhir. Akatel Sandhy Putra Purwokerto.

[13] Wibisono, Gunawan dan Hantoro, Gunadi Dwi. 2006. Wimax Teknologi Broadband Wireless Access (BWA) Kini dan Masa Depan. Bandung: Informatika.

[14] Wibisono,Gunawan dan Hantoro,Gunadi Dwi dkk. 2008. Peluang dan Tantangan Bisnis WiMAX di Indonesia. Bandung: Informatika.

[15] Wibisono, Gunawan dan Hantoro Gunadi Dwi. 2008. Mobile Broadband Trend Teknologi Wireless Saat Ini dan Masa Datang. Bandung: Informatika.

[16]http://www.wimaxforum.org/technology/ downloads/Mobile_WiM AX_Part1_Overview_and_Performanc e.pdf. Diakses pada tanggal 14 Januari 2012 Pukul 14.30 WIB.

[17]http://shirotholmustaqim.files.wordpress.c om/2010/02/dasar- pemrogramanvisual-basic1.pdf. diakses pada Tanggal 2 Mei 2012. Pukul 20.47 WIB 